\title{
The Orientation of Value, Motivation and Pro-Social Attitude: The Influence to Entrepreneurship Learning and Student Entrepreneur Competence
}

\author{
Mohammad Maskan ${ }^{1}$, Awan Setiawan ${ }^{2}$ \\ \{alifmaskan@gmail.com1, awansetiawan@polinema.ac.id2\} \\ Politeknik Negeri Malang, Indonesia ${ }^{1,2}$
}

\begin{abstract}
This research aims to study entrepreneurship learning and competence based on value orientation, motivation, and pro-social behavior of students at Vocational Senior High School. The alumni of vocational high school ideally become entrepreneur, until this becomes the responsibility of vocation institution to teach the values which focus on growing the spirit of entrepreneurship at Vocational High School Frateran dan Cor Jesu in Malang City. This research was conducted at Vocational High School Frateran dan Cor Jesu in Malang City with 100 research samples. Data analysis used descriptive and Structural Equation Modeling. The research results show that: (1) Value orientation, motivation, and pro-social behavior have positive and significant effect towards entrepreneurship learning, (2) Value orientation, motivation and pro-social behavior and entrepreneurship learning simultaneously have effect towards entrepreneurship competence. The recommendation is that: the teacher of entrepreneurship subject needs to prepare learning materials in the form of module with constructivist learning model and contextual approach which correlates the theory of entrepreneurship and its practice in family environment and the society surround them, until it can grow the entrepreneurship competence.
\end{abstract}

Keywords: Value Orientation, Motivation, Pro-social Behavior, Entrepreneurship Learning, Entrepreneurship Competence.

\section{Introduction}

This research is conducted in Frateran dan Cor Jesu Vocational High School in Malang with the majority ethnic group of Chinese. This matter is based on the analysis of Chinese ethnic group in Malang that the economical aspect can be considered as high, where most of them work as entrepreneurs, so they have good entrepreneurship competence that makes their business successful. In other hand, the Chinese way of thinking is influenced by Taoism and Confucianism, also always attempts to make a better life than other, hardworking, persevering, saving, patience and thorough. Confucian value is one of the factors that influence the success of Chinese ethnic group such as family and hierarchy disipline in the society, also has high solidarity [1].

While the Javanese society, according to Ibrahim and Kodiran [2], its other living source than entrepreneurship are crafting and trading also farming. So that mentality of Javanese ethnic group that can hamper the developments of entrepreneurship are (a) Too accepting and passive on their life; (b) Population pressure which has caused villagers in Java poor; (c) 
There are no original organizations which has settled which has modernized can turn into active and creative society organization, and (d) There is no active and creative leadership to lead the production activities which can give three to four times more than before.

There are some implications toward the difference of entrepreneurship value, motivation, prosocial attitude and competence on Javanese and Chinese students in Malang. So teachers of entrepreneurship subject that has multi-ethnic student which should make accurate lesson plan, as appropriate with the culture and value adhered to the students, such as the education of entrepreneurship in the countries with multi-ethnic group. As said by Carayannis et al [3] that schools across the educational system need to work together to promote entrepreneurship education and entrepreneurial values in all phases of the educational life cycle. The research question is: Is there a significant influence between the orientations of pro-social value, business motivation and attitude related to the lesson in order to develop entrepreneurship competence of Chinese and Javanese ethnic group at VHS in Malang.

\section{Literature Review}

The research of Cunningham to 178 professional entrepreneurs and managers in Singapore, show that success is related to the personality (49\%), such as the woll to do good work, to be successful, self-motivation, self-confidence and psitive thinking, commitment and patience. Collins [4] findings of the relation between value orientation in the family to the business motivation which influenced in the entrepreneurship learning. The success of students on entrepreneurship learning also able to increase the entrepreneur competence which has been supported by nine entrepreneur character [5]. However, a successful can be related to the educational level, experience, and age [3][6]. Education is more associated with entrepreneur's succes [7] proves that brief experience has no influence on the success, but enterpreneurial age, which means how long a person has become an entrepreneur has influenced significantly. Business experience can be obtained from early age guidance by parents who also entrepreneur or from the working experience in an entrepreneurial organization.

Personality character that support the entrepreneurship success are creative and inovative. Druker [8] also confirmed that to achieve success an entrepreneur must learn how to implement the inovation systematically. While, Maskan [5] on his dissertation proves that planned intervention can form dominant traits of entrepreneurs, and there are 9 dominant of entrepreneurs such as: instrumental, achievement-oriented, get along well, hardworking, selfconfidence, self-control, innovative, and independent.

Theory of connectionism (law of exercise) by Thorndike said that learning effectiveness is depending on the student's readiness (law of readiness), student's interest (law of effects), and use-disused learning material (law of use-disuse). A person who has a strong interest and motivation in studying and implement its study result will master the field of study. Meanwhile, according to field theory of Kurt Lewin said that a person attitude is depending on individual characteristics environment condition (Behavior $=\mathrm{f}$ (person, environment)). Environment can become a supporting or hampering factor. Bandura said that learning can be done with belief-oriented approach, affection-oriented approach, or behavior-oriented approach [9].

Maskan [5] reviewed that entrepreneur competence is knowledge that have student about what entrepreneurship, entrepreneur attitude and skills to manage business that can be measure 
with questionnaire and entrepreneur practice. Based on theorities and empiricals review, so can be show relationship between dependent variables and independent variable in the figure 1.

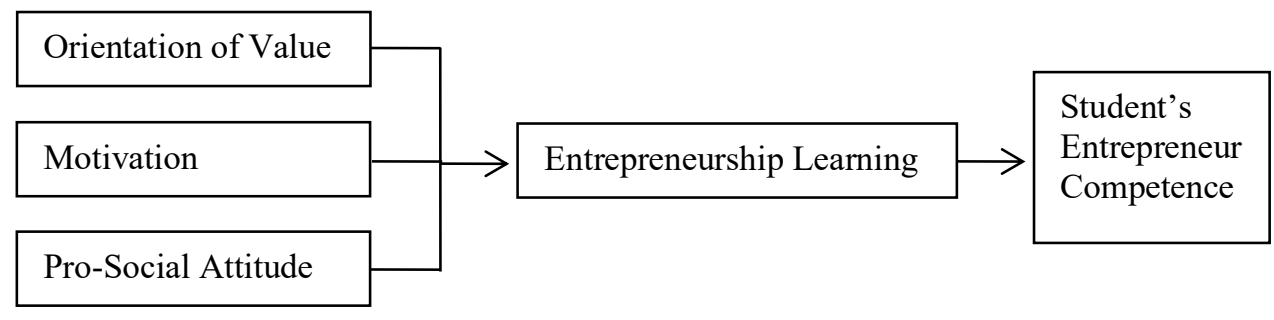

Fig. 1. Relationship Between Dependent and Independent Variables.

\section{Research Methods}

This research method was explanatory research or hypothesis testing. The respondents were 100 SHS students of Javanese and Chinese ethnic group in Frateran dan Cor Jesu VHS in Malang. The sample collection was done in random sampling. The data collection method was with survey, with some enumerators which had been directed. The data analysis used was Structural Equation Modeling.

\section{Results and Discussion}

The hypothesis of this research can be found as follows: positive and significant value orientation influence student's motivation and pro-social attitude; positive and significant value orientation influence the entrepreneurship learning; positive and significant motivation influence the entrepreneurship learning; positive and significant pro-social attitude influence the entrepreneurship learning; the orientation of value, motivation and pro-social attitude give positive and significant influence to the entrepreneurship learning; the orientation of value, motivation, and pro-social attitude and also entrepreneurship learning can give positive and significant influence to the entrepreneur compentence.

According to the research analysis, it is known that the influence between value orientation to the motivation, between the motivation and the pro-social attitude is significant. This matter can be explained in descriptive that students aspiration in major is job seeker, where from 47 students $(62,5 \%)$ are happier to be an entrepreneur. Furthermore, it is also influence by parents job background 78,6\% (44 parents) are entrepreneur. Therefore, based on empirical and theoretical review related to the difference on the relation between the orientations of value and motivation of the students are considered understandable. In line with Salladien [10] which argued that a student will attracted to learn about entrepreneurship when they find self-confident that entrepreneurship will guarantee the future. The result of the research supports Purnomo [11] research which said that in a whole or partial, education variable, ethnic group, gender, parents job and living environment have a significant relation with the entrepreneurship attitude (contribution of $51,7 \%$ ). 
On the other hand, the supporting factor of student readiness to do business is achievement on study which has oriented to entrepreneur competence. This matter strengthens Suparman [12] research result, where there is correlation between entrepreneurship learning to the student interest to entrepreneurship. A dimension to raise and grow some kinds of business is by developing working skills which is needed in the working field as suitable with the interest and capability of an individual. This explains that student's entrepreneurship competence in VHS has positively correlated with the entrepreneurship knowledge.

\section{Conclusion}

Hypothesis accepted confirms that: (1) value orientation has influenced positive and significant to the students motivation of Chinese ethnic group in entrepreneurship, while the Javanese happens vice versa; (2) The orientation of value, motivation and pro-social attitude for Chinese ethnic group students has positive and significant toward the entrepreneurship learning, while the Javanese happens vice versa; (3) The orientation of value, motivation, prosocial attitude and entrepreneurship learning is simultaneously influences positive and significant toward the entrepreneurship competence of Chinese students, while Javanese students happen vice versa.

Hypothesis rejected confirms that: (1) the orientation of value is positively and significantly influenced the students' pro-social attitude. The positive and significant motivation influence the pro-social attitude; (2) the orientation of value has positively and significantly influence the entrepreneurship learning; (3) the motivation is positively and significantly influence the entrepreneurship learning; and (4) Pro-social attitude positively and significantly influence the entrepreneurship learning.

\subsection{Sugestion}

It must grow the entrepreneurship value orientation and motivate students in order to follow the entrepreneurship learning, also form the pro-social attitude, schools need to conduct fixation in the learning-teaching process with Student Centered Learning (SCL) approach, learning guide system and the revamping the learning method on contextual-oriented based on multimedia. For the further researcher, it is better to focus on the development of entrepreneurship learning model with multi-cultural base learning in VHS in Malang.

\section{References}

[1] G. Wirawan, "Perbedaan Orientasi Nilai dan Perilaku Prososial antara Suku Bangsa Melayu dan Suku Bangsa Tionghoa." 2004.

[2] M. . Y. Ibrahim and M. A. Kodiran, "Perubahan sikap dan perilaku pengungsi kerusuhan Sambas serta dampaknya terhadap ketahanan asset pemerintah daerah:: Studi kasus Pendirian bangunan liar di lokasi gedung milik Pemerintah Daerah di Kota Pontianak." [Yogyakarta]: Universitas Gadjah Mada, 2002.

[3] E. G. Carayannis, D. Evans, and M. Hanson, “A cross-cultural learning strategy for entrepreneurship education: outline of key concepts and lessons learned from a comparative study of entrepreneurship students in France and the US," Technovation, vol. 23, no. 9, pp. 757$771,2003$.

[4] C. J. Collins, P. J. Hanges, and E. A. Locke, "The relationship of achievement motivation to 
entrepreneurial behavior: A meta-analysis," Hum. Perform., vol. 17, no. 1, pp. 95-117, 2000.

[5] M. Maskan, "Pengembangan Model Pembelajaran Kewirausahaan Berbasis Student Center Learning pada Siswa SMK di Kota Malang,” Universitas Negeri Malang, 2010.

[6] S. A. Alvarez and L. W. Busenitz, "The entrepreneurship of resource-based theory," $J$. Manage., vol. 27, no. 6, pp. 755-775, 2001.

[7] J. Thompson, G. Alvy, and A. Lees, "Social entrepreneurship-a new look at the people and the potential," Manag. Decis., 2000.

[8] P. Druker, "Innovation and entrepreneurship: Practice and principles," NY Harper\& Row, 1985.

[9] D. Sudjana, Manajemen program pendidikan untuk pendidikan luar sekolah dan pengembangan sumber daya manusia. Falah Production, 2000.

[10] Salladien, "Alternatif Pedidikan Berorientasi Dunia Kerja sebagai Upaya Menghadirkan SDM Berkompetensi di Era Otonomi Daerah. Makalah Seminar Nasional Peningkatan Pembangunan Regional di Era Otonomi Daerah, Kerjasama Program Pascasarjana Universitas Brawijaya dengan, , 2005.

[11] B. H. Purnomo, "Analisis Hubungan Pendidikan, Etnis, Gender, Pekerjaan Orang Tua, Lingkungan Tempat Tinggal, Dengan Sikap Kerwirausahaan Para Siswa SMK Di Kota Jember," Universitas Negeri Malang, 2014.

[12] Suparman, Perbedaan Orientasi Nilai dan Perilaku Prososial antara Suku Bangsa Melayu dan Suku Bangsa Tionghoa. Pekanbaru: Bumipustaka, 2013. 